\title{
- PROBLEMY PIELĘGNACYJNE POJAWIAJĄCE SIE, W PROCESIE GOJENIA RAN NOWOTWOROWYCH
}

\section{NURSING DIAGNOSIS OCCURRING IN THE PROCESS OF CANCER'S WOUND HEALING}

\author{
Dorota Bitiucka ${ }^{1}$, Regina Sierżantowicz ${ }^{2}$ \\ ${ }^{1}$ Studenckie Koło Naukowe przy Zakładzie Pielęgniarstwa Chirurgicznego \\ Uniwersytet Medyczny w Białymstoku \\ ${ }^{2}$ opiekun Studenckiego Koła Naukowego przy Zakładzie Pielęgniarstwa Chirurgicznego \\ Zakład Pielęgniarstwa Chirurgicznego \\ Uniwersytet Medyczny w Białymstoku
}

DOI: http://dx.doi.org/10.20883/pielpol.2016.18

\begin{abstract}
STRESZCZENIE
Rana przewlekła jest rodzajem rany, pozostającej w ciągłej fazie zapalnej, upośledzającej regenerację i odbudowę anatomicznej oraz fizjologicznej spójności. Charakteryzuje się niedostatecznym gojeniem mimo stosownego leczenia przez długi okres. Szereg czynników ogólnoustrojowych i czynników miejscowych utrudnia proces gojenia się rany. Rany nowotworowe, powstające na skutek rozsiewu nowotworowego w organizmie człowieka, i związane z nimi głębokie uszkodzenia tkanki skórnej powodują wiele problemów pielęgnacyjnych. Wśród nich na szczególną uwagę zasługują: znaczny wysięk z rany i fetor wydobywający się z rany, krwawienie z rany, ryzyko wystąpienia zaburzeń wodno-elektrolitowych, postępujący ból oraz problemy psychiczne związane z oszpeceniem ciała.

Celami pracy były: próba oceny rozpoznania najczęstszych problemów pielęgnacyjnych pacjenta z raną nowotworową oraz ukazanie działań pielęgniarskich zmniejszających dolegliwości chorego. Dokonano także krytycznej analizy literatury.
\end{abstract}

SŁOWA KLUCZOWE: rana nowotworowa, problemy pielęgnacyjne, materiały opatrunkowe, holistyczny model opieki pielęgniarskiej.

\section{Wprowadzenie}

Rana przewlekła jest rodzajem rany, pozostającej w ciągłej fazie zapalnej, upośledzającej regenerację i odbudowę anatomicznej oraz fizjologicznej spójności. Charakteryzuje się niedostatecznym gojeniem mimo stosownego leczenia przez długi okres. Przewlekły charakter rany związany jest z ciągłym narażeniem na zakażenie drobnoustrojami [1]. Leczenie ran wymaga całościowej interakcji między komórkami naskórka, skóry właściwej i tkanek położonych pod nią. Szereg czynników ogólnoustrojowych i czynników miejscowych utrudnia proces gojenia się rany. Najczęściej w chorobach nowotworowych tymi czynnikami są: podeszły wiek, niedożywienie i wyniszczenie, choroby przewlekłe, przyjmowane leki, palenie tytoniu oraz

\begin{abstract}
Cancer wound is a type of a chronic wound, remaining in the continuous phase of the inflammatory, impairing the regeneration and restoration of anatomical and physiological coherence. The cancer wound does not heal even when it is worthily treating. The healing process is inhibited by general and local factors. Increasing problems have a disadvantageous influence on a patient, his family and medical staff. Those problems are: exudation and foetor coming from the wound, bleeding from the wound, the risk of water - electrolyte imbalance, chronic pain and psychical problems related to body disfigurement.

The aim of the study was the research of literature in the field of identifying the most common nursing problems occurring in the process of cancer wound healing and submiting the nursing care which decreases patient's complaints.
\end{abstract}

KEYWORDS: cancer wound, nursing problems, dressing materials, holistic type of treatment.

rozległy rozsiew nowotworowy. Nie bez znaczenia są też miejscowe problemy, jak zakażenie rany, obecność tkanki martwiczej, obecność ciała obcego, uraz mechaniczny, a także przewlekły ucisk [2, 3]. Rany nowotworowe powstają w wyniku uszkodzenia tkanki skórnej na skutek rozsiewu nowotworowego w organizmie człowieka. Komórki nowotworowe, dostając się do krwi lub limfy, osadzają się w drobnych naczyniach krwionośnych, powodując zaburzenia ukrwienia skóry, zaczerwienienie, obrzęk oraz ubytek naskórka i martwicę, a w konsekwencji owrzodzenie skóry. Uszkodzenia te występują w nowotworach pierwotnych, np. w nowotworze głowy lub skóry, a także są konsekwencją przerzutów. Przerzutowe uszkodzenia skóry powstają w wyniku procesu nowotworowego toczącego się w płucach, piersiach, jelicie 
grubym i skórze właściwej. Najczęściej rany nowotworowe powstają na klatce piersiowej, głowie i szyi, plecach, tułowiu i brzuchu, pachwinie i pachach, genitaliach oraz kończynach [4]. Dokładna ocena rany jest niezbędna w początkowym etapie leczenia i pielęgnowania. Ocena ta obejmuje nie tylko uszkodzenie tkanek, ale także stan bio-psycho-społeczny pacjenta i diagnozę lekarską. Zebrane dane pozwalają na zaplanowanie indywidualnej opieki nad chorym. Do oceny rany nowotworowej używa się skal, które klasyfikują stan rany, wysięk, krwawienie, zapach, świąd i intensywność dolegliwości bólowych. Jedną ze skal jest system oceny TIME, T usuwanie martwych tkanek, I - kontrola i ograniczenie namnażania się bakterii, $\mathrm{M}$ - zminimalizowanie wysięku oraz fetoru, E - zmniejszenie uszkodzenia tkanki skórnej wokół rany. W celu oceny głębokości i uszkodzenia tkanek stosowane są czterostopniowe skale, takie jak Melignant Cutaneous Wound (MCW) oraz National Presure Ulcer Advisory Panel (NPUAP), używana także w ocenie odleżyn [5]. Rozległe i głębokie rany, pojawiające się wraz ze wzrostem rozsiewu nowotworowego, powodują szereg komplikacji miejscowych i ogólnych. Narastające problemy wpływają niekorzystnie na pacjenta, ale także na jego rodzinę i personel medyczny. Wśród problemów zdrowotnych istotne znaczenie w tej kwestii mają: znaczny wysięk z rany i fetor wydobywający się z rany, krwawienie z rany, ryzyko wystąpienia zaburzeń wodno-elektrolitowych, postępujący ból oraz problemy psychiczne związane z oszpeceniem ciała [4].

Celami pracy były: próba oceny rozpoznania najczęstszych problemów pielęgnacyjnych pacjenta z raną nowotworową oraz ukazanie działań pielęgniarskich zmniejszających dolegliwości chorego. Dokonano także krytycznej analizy literatury.

\section{Wysięk i fetor wydobywające się z rany nowotworowej}

Znaczny wysięk z rany nowotworowej utrudnia utrzymanie czystości założonego opatrunku, higieny ciała chorego oraz jego otoczenia. Wilgotne środowisko i złuszczający się naskórek zwiększają ryzyko infekcji bakteryjnej, co w konsekwencji prowadzi do namnażania się drobnoustrojów, zarówno tlenowych, jak i beztlenowych. Pierwszym etapem w okresie miejscowego leczenia i pielęgnacji rany nowotworowej jest dokładne oczyszczenie. Metodą oczyszczenia może być chirurgiczne opracowanie rany lub wykorzystanie środków autolizujących, np. hydroterapia 0,9-procentowym $\mathrm{NaCl}$ ze środkiem antyseptycznym stosowane na ranę pod ciśnieniem. Niezbędna jest też dekontaminacja rany oraz zmiana opatrunków. Materiał do zaopatrywania rany nowotworowej powinien spełniać następujące kryteria:

1) zapewnienie fizjologicznej stałości rany,
2) ścisłe przyleganie do uszkodzonej tkanki,

3) pochłanianie nadmiaru wysięku i zabezpieczenie przed jego wyciekiem,

4) zmniejszanie nieprzyjemnego zapachu,

5) zapewnienie wilgotności rany, termoregulacji, wymiany gazowej i optymalnego pH dla skóry,

6) ochrona przed infekcjami i bodźcami zewnętrznymi,

7) zminimalizowanie dolegliwości bólowych,

8) antyalergiczność [1, 4, 6, 7].

Praca pielęgniarska w kontekście holistycznej opieki w procesie leczenia ran nowotworowych obejmuje zadania diagnostyczne, terapeutyczno-pielęgnacyjne, opiekuńcze, edukacyjne i rehabilitacyjne. Pielęgniarka ocenia stan bio-psycho-społeczny pacjenta i podejmuje działania w celu zmniejszenia dolegliwości chorego. Zminimalizowanie wysięku i nieprzyjemnego zapachu zapewniają materiały opatrunkowe. Dobór opatrunków zależy od natężenia negatywnych czynników, stanu i rozległości rany oraz stanu ogólnego pacjenta $[4,8]$. W przypadku rany zainfekowanej wykorzystuje się opatrunki z jonami srebra, gdyż są skuteczne w zwalczaniu drobnoustrojów i zmniejszaniu przykrego zapachu $z$ rany. Rany leczone opatrunkami z jonami srebra goją się szybciej niż rany opatrywane zwykłymi materiałami. Opatrunki z jonami srebra stosuje się jako alternatywę dla antybiotyków i chemioterapeutyków; nie powodują oporności drobnoustrojów na substancje czynne [9, 10]. Rekomendowane opatrunki do ran z czynną infekcją to opatrunki hydrowłókniste $z$ jonami srebra oraz opatrunki piankowe z zawartością srebra [11].

Do pochłaniania znacznego wysięku z rany nowotworowej używa się gąbek poliuretanowych. Utrzymują one stałą wilgotność i temperaturę w miejscu uszkodzenia tkanek oraz zapewniają stałą wymianę gazową. Zaleca się ich stosowanie ze środkami przeciwdrobnoustrojowymi czy środkami antyseptycznymi lub antybiotykami. Samodzielne ich zastosowanie może opóźniać gojenie rany [12].

Skuteczne w odprowadzaniu nadmiernej ilości wydzieliny są także materiały hydrokoloidowe, które utrzymują wilgotność uszkodzonej tkanki i hamują namnażanie się drobnoustrojów w jej wnętrzu [13]. Kolejnymi efektywnymi materiałami absorpcyjnymi są dekstranomery, a uzupełniający oczyszczający mechanizm działania pozwala na ich wykorzystanie na owrzodzenia o dużym wysięku oraz owrzodzenia zainfekowane, wymagające oczyszczenia [12].

Wykorzystywanymi w procesie wchłaniania i niwelowania nieprzyjemnego zapachu są również opatrunki typu hydrofiber. Ich cechą charakterystyczną jest zatrzymywanie wysięku wraz z drobnoustrojami wewnątrz opatrunku oraz zapobieganie maceracji i podrażnieniu skóry wokół rany [14]. 
Podkreślić należy, że w pielęgnacji ran nowotworowych każdy zastosowany opatrunek powinien być dopasowany do wielkości rany i fazy jej gojenia oraz szczelnie przylegać do uszkodzonej tkanki. Opatrunek należy bezwzględnie wymienić, jeśli pojawią się silny ból, podwyższona temperatura ciała, przekrwienie lub przeciążenie pochłanianym wysiękiem oraz jego destabilizacja w miejscu założenia. Przy każdej zmianie zastosowanego materiału należy ocenić stan uszkodzonej tkanki, jej głębokość, rodzaj wysięku, natężenie zapachu, obecność tkanki martwiczej, fazę gojenia i obecność objawów czynnej infekcji, takich jak: obrzęk, podwyższona temperatura ciała, zaczerwienienie, fetor, obecność w ranie złogów ropy $[4,8]$.

Do zminimalizowania nieprzyjemnego zapachu z rany nowotworowej można zastosować także preparaty antyseptyczne. Najczęściej wykorzystuje się dobrze znane preparaty, takie jak: 3-procentowy nadtlenek wodoru, 1-procentowa chlorheksydyna, kwas borny lub 3-5-procentowy kwas octowy. Użycie środków powinno być poprzedzone dokładną oceną rany. W badaniach M. Sopaty i wsp. [15] stwierdzono, że zastosowanie chlorowodorku oktenidyny powoduje pozytywny efekt w minimalizacji wysięku, eradykacji bakterii oraz zredukowaniu tkanki martwiczej. Zastosowanie chlorowodorku oktenidyny powoduje też zmniejszenie kolonizacji ran owrzodzeniowych przez drobnoustroje, jak S. aureus czy P. mirabilit. Preparaty z chlorowodorkiem oktenidyny wykorzystuje się zarówno do odkażenia uszkodzonych tkanek, jak i zaopatrzenia rany [15].

\section{Krwawienie z rany}

Krwawienie z rany jest wynikiem mechanicznego uszkodzenia bogato unaczynionej, nowo powstałej tkanki nowotworowej. Ubytek krwi utrudnia zaopatrzenie rany, potęguje niedokrwistość, zwiększa ryzyko zakażenia rany. W przypadku masywnego krwotoku z rany nowotworowej podejmuje się decyzje o chirurgicznym opracowaniu uszkodzonej tkanki lub mniej inwazyjnym działaniu, jakim jest embolizacja owrzodzeń [16].

W celu powstrzymania krwotoku wykorzystuje się również radioterapię miejsca krwawienia i substancje o działaniu hemostatycznym [16, 17]. Do zminimalizowania krwawienia z rany używa się także materiałów opatrunkowych zawierających jony srebra o różnym stężeniu, ponieważ im wyższe stężenie cząsteczek srebra, tym większe działania koagulacyjne. Dodatkowo materiały te zawierają parafinę zmniejszającą ryzyko przyklejenia się opatrunku do powstałych zmian [10]. Niektóre opatrunki algininowe mają właściwości hemostatyczne. Jony wapnia powodują aktywację płytek krwi i przyspieszają kaskadę procesów krzepnięcia krwi. Materiały algininowe mają zastosowanie w ranach z dużym wysiękiem oraz w przewlekłych ranach głębokich, szczelinowych i w wilgotnych owrzodzeniach pokrytych dużą warstwą włóknika. Nie należy ich stosować w ranach suchych i „czystych” [18]. Wspomniane wcześniej opatrunki typu hydrofiber również znajdują zastosowanie w zmniejszeniu krwawienia z rany, ponieważ wykazują działanie fibrynolityczne i pobudzają angiogenezę [14]. Działaniami zmniejszającymi ryzyko wystąpienia krwotoku z rany są: ostrożna zmiana opatrunków, chirurgiczne opracowanie martwiczej tkanki, zminimalizowanie wysięku oraz zabezpieczenie uszkodzonych tkanek przed urazem mechanicznym. Dodatkowo można zastosować opaski uciskowe i okłady z lodu, jednak nie będą one skuteczne przy silnym krwawieniu. Przy zmianie materiałów opatrunkowych należy pamiętać o nasączeniu ich preparatem o działaniu hemostatycznym - roztworem kwasu traneskamowego, lub antyseptycznym - roztworem chlorowodorku oktenidyny [4].

\section{Ryzyko wystąpienia zaburzeń wodno- -elektrolitowych}

Zły stan ogólny pacjenta, krwawienie i znaczny wysięk $z$ rany nowotworowej stwarzają ryzyko wystąpienia zaburzeń wodno-elektrolitowych. W celu zmniejszenia ryzyka należy podjąć następujące działania profilaktyczne:

1) kontrolę parametrów życiowych: ciśnienia tętniczego krwi, tętna, oddechów 4 razy dziennie oraz temperatury 2 razy dziennie,

2) obserwację pacjenta pod kątem odwodnienia: napięcie skóry i gałek ocznych, kontrola błony śluzowej jamy ustnej i ocena stanu języka,

3) przy każdym kontakcie z pacjentem ocenę stanu opatrunków założonych na ranie oraz ich tempa przesiąkania,

4) zmianę przesiąkniętych opatrunków z zachowaniem zasad aseptyki i antyseptyki,

5) kontrolę diurezy dobowej i prowadzenie bilansu wodno-elektrolitowego,

6) pobranie krwi obwodowej do diagnostyki laboratoryjnej na stężenie elektrolitów, mocznika i kreatyniny, a także do oceny hematokrytu,

7) podanie płynów infuzyjnych i leków drogą dożylną zgodnie z indywidualną kartą zleceń lekarskich [3, 4].

\section{Postępujące dolegliwości bólowe}

Postępujący ból dotyczy toczącego się procesu nowotworowego i samej rany nowotworowej. Pacjenci onkologiczni cierpią z powodu bólu przewlekłego, który przebiega z wyraźnymi zaostrzeniami. Doznania bólowe rany nowotworowej stają się większe, gdy uszkodzenie tkanek jest rozległe, pojawiają się znaczny wysięk z rany, przykry zapach oraz krwotok. Dodatkowymi 
czynnikami potęgującymi ból są brak postępu w leczeniu rany nowotworowej, oszpecenie i odrzucenie ze strony środowiska [4].

W celu uzyskania pełnego obrazu dolegliwości bólowych używa się skal oceniających natężenie bólu, takich jak: skala VAS (wizualna skala analogowa) oraz skala NRS (numeryczna skala bólu), poza tym duże znaczenie mają wnikliwa obserwacja chorego i rany nowotworowej oraz umiejętność dokładnego wysłuchania pacjenta [4, 19].

Pacjenci onkologiczni leczeni są środkami analgetycznymi według drabiny analgetycznej Światowej Organizacji Zdrowia (WHO) zgodnie ze zleceniem lekarza. Najczęściej stosowanymi środkami przeciwbólowymi są preparaty opioidowe. Dodatkowymi elementami uśmierzającymi ból są indywidualnie dobrane dla pacjenta materiały opatrunkowe, profesjonalna zmiana opatrunków oraz substancje działające miejscowo, jak zimno suche lub środki miejscowo znieczulające [4, 19].

\section{Problemy psychiczne związane z oszpeceniem ciała}

Opieka pielęgniarska nie powinna być skoncentrowana tylko na sferze biologicznej chorego. Holistyczny model opieki postrzega problem całościowo, z uwzględnieniem stanu psychospołecznego pacjenta [4].

Rana nowotworowa, oszpecając ciało chorego, w szczególny sposób wpływa na jego stan psychiczny. Rozległe, bolesne uszkodzenia, o odrażającym zapachu, mają bardzo niekorzystny wpływ na podejście pacjenta do choroby, do własnego ciała oraz czynności dnia codziennego. Chory z raną nowotworową, widząc brak postępu w leczeniu, rezygnuje z walki z chorobą oraz unika kontaktu, pogłębiając odosobnienie. Zaniedbanie złego stanu psychicznego pacjenta może doprowadzić do poczucia winy, depresji, zaburzeń snu i odżywiania, a także niesprawności fizycznej [4, 16, 19].

Największym problemem wpływającym na stan psychiczny pacjenta jest znaczny wysięk powiązany z fetorem wydobywającym się z rany. Przykry zapach przenika przez ubrania, może powodować nudności i wymioty, a w konsekwencji wstręt do samego siebie. Należy zadbać o szczelność założonego opatrunku i higienę osobistą oraz otoczenia pacjenta. Poprawić samopoczucie chorego mogą pokazywanie najmniejszych postępów w procesie leczenia rany, zachęcanie chorego do aktywności w czynnościach dnia codziennego, wykazywanie empatii oraz cierpliwości $[4,16,19]$.

\section{Alternatywne metody leczenia ran nowotworowych}

Wśród najnowszych badań biologicznych w leczeniu i pielęgnacji ran przewlekłych na uwagę zasługują opa- trunki pochodzenia naturalnego. Wyniki badań uzyskane w metodzie in vitro, na modelach zwierzęcych i podczas prac klinicznych udowodniły, iż pozytywne działanie w leczeniu ran przewlekłych wykazały antyoksydanty, np. witamina E [20]. Przykładem materiałów pochodzenia naturalnego są opatrunki z transgenicznego Inu. To materiały zaprojektowane z włókien Inu, oleju i ekstraktu z nasion. Przeprowadzone przez K. Skórkowską-Telichowską i wsp. [21] 12-tygodniowe badania z użyciem opatrunków z zawartością Inu wykazały zmniejszenie rozmiarów ran w $80 \%$ przypadków w grupie 30 pacjentów z przewlekłym owrzodzeniem żylnym, zmniejszenie wysięku u $67 \%$ badanych oraz zminimalizowanie bólu wśród $96 \%$ badanych. U mniej niż $20 \%$ pacjentów rany uległy powiększeniu. Stwierdzono również, że opatrunki te zastosowane na rany przewlekłe wpłynęły na zmniejszenie zmian owrzodzeniowych u pacjentki ze stopą cukrzycową po 12-tygodniowej terapii [22].

Najnowsze badania kliniczne wykazują skuteczność działania owocu Carrica papaia w leczeniu przewlekłych ran, a także w ranach pooperacyjnych i oparzeniach. Badania przedkliniczne przeprowadzono na gryzoniach. Wykazano zwiększone ziarninowanie rany u chorych na cukrzycę gryzoni, dodatkowo zauważono działanie antybakteryjne na $S$. aureus i $P$. aeruginosa [23]. Badania na ranach u szczurów leczonych ekstraktem z ziaren papai udowodniły znaczne zmniejszenie się ran po 13 dniach od zastosowania kuracji. Ponadto w uszkodzonych tkankach w badaniu histopatologicznym odnotowano zwiększoną ilość włókien kolagenowych w porównaniu do grupy kontrolnej [24].

Kolejną alternatywą w zaopatrywaniu ran nowotworowych jest miód - najstarsza substancja naturalna stosowana leczniczo. Najnowsze opatrunki z zawartością miodu stosowane są w formie hydrożeli, alaginianów i hydrokolidów. W badaniach klinicznych przeprowadzonych w Malezji przez R.M. Zohdi i wsp. [26] wykorzystano opatrunki z zawartością miodu i zastosowano na rany pooperacyjne, oparzeniowe, owrzodzenia towarzyszące w zespole stopy cukrzycowej i owrzodzenia żylne kończyn dolnych. W pierwszych trzech grupach pacjentów wykazano korzystny wpływ na proces gojenia się rany, zaś w owrzodzeniach goleni odnotowano zmniejszone dolegliwości bólowe jako jedyny efekt terapeutyczny [25].

Naturalne olejki znalazły zastosowanie w leczeniu ran przewlekłych. Pierwszym z nich jest olejek pomarańczowy. $\mathrm{W}$ badaniu metodą in vitro zauważono, że opatrunki z olejkiem pomarańczowym wykazują właściwości antybakteryjne wobec szczepów gronkowca złocistego MRSA (gronkowiec złocisty oporny na metycylinę) i VISA (gronkowiec złocisty średnio oporny na 
wankomycynę). Dodatkowo nie wykazano toksycznego działania olejku na komórki naskórka ludzkiego. Olejek dodano również do hodowli ludzkich keratynocytów zarażonych $S$. aureus, co spowodowało wyeliminowanie zakażenia [26].

Kolejny olejek stosowany na rany i owrzodzenia to olejek eukaliptusowy. Badania nad tym olejkiem wykazały jego właściwości antybakteryjne oraz zdolność do wiązania toksyn drobnoustrojów, przez co jest on bezpieczny w użyciu jako preparat antyseptyczny. Zastosowanie mieszanki olejku eukaliptusowego z cytrynowym, goździkowym i tymiankowym skutkowało działaniem przeciwzapalnym i znacznym zmniejszeniem wydzielającego się fetoru z wrzodziejących ran głowy i szyi [27].

Skuteczny w leczeniu i pielęgnacji ran przewlekłych okazał się również kwasek cytrynowy. Badania zostały przeprowadzone w Indiach przez B.S. Nagoba i wsp. [28] w grupie 34 pacjentów z przewlekłymi owrzodzeniami. Zastosowano maści z kwaskiem cytrynowym z miękką parafiną. Owrzodzenia były ranami zainfekowanymi, najczęściej przez szczepy S. aureus i Klebsiella. Miejscowe zastosowanie maści z kwaskiem cytrynowym spowodowało w 73\% przypadków wyleczenie rany, a u pozostałych badanych zaobserwowano wyeliminowanie czynnego zakażenia drobnoustrojami i powstanie ziarniny, lecz nie odnotowano całkowitego wygojenia się rany [28].

\section{Podsumowanie}

Obecność ran przewlekłych u pacjenta w przebiegu procesu nowotworowego znacznie utrudnia lub uniemożliwia aktywność codzienną chorego oraz niekorzystnie wpływa na jego postawę i motywację w walce z chorobą. Zarówno pacjenci, jak i personel pielęgniarski borykają się z trudnościami w procesie leczenia i pielęgnacji ran nowotworowych. Obecnie nie ma formalnych zaleceń i standardów, na których zespół terapeutyczny mógłby oprzeć działania praktyczne. Przegląd literatury z zakresu pielęgnacji ran nowotworowych umożliwił zebranie danych, na podstawie których można zgłębić problematykę tego tematu. Zastosowanie opatrunków nowoczesnej generacji i alternatywnych metod leczenia ran przewlekłych, których skuteczność potwierdzono badaniami klinicznymi, znacznie poprawia stan ogólny pacjenta oraz gojenie rany. Postępy w gojeniu ran oraz zminimalizowanie krwawienia i wysięku z rany pozytywnie wpływają na jakość życia pacjenta i walkę $z$ chorobą nowotworową $[4,5,8]$.

\section{Piśmiennictwo}

1. Skórkowska-Telichowska K, Bugajska-Prusak A, Pluciński P et al. Fizjologia i patologia przewlekle niegojących się owrzodzeń oraz sposoby ich miejscowego leczenia w świetle współczesnej wiedzy medycznej. Dermatol Prakt. 2009; 5: 15-29.
2. Ziółkowski G, Ochocka B, Malara M et al. Pielęgnacja skóry i rany. Katowice: Polskie Stowarzyszenie Pielęgniarek Epidemiologicznych; 2011.

3. Ścisło L, Kowalewska M. Rany. W: Ścisło L, Walewska E (red.). Procedury pielęgniarskie w chirurgii. Warszawa: PZWL; 2012. 59-142.

4. Bazaliński D, Chmiel Z, Kózka M. Opieka pielęgniarska nad pacjentem z raną nowotworową. W: Szewczyk MT, Jawień A (red.). Leczenie ran przewlekłych. Warszawa: PZWL; 2012. 162-167.

5. Kelly J. Methods of wound debridement: a case study. Nurs Stand. 2010; 25: 51-59.

6. Pielesz A, Paluch J. Opatrunki aktywne - biomateriały w badaniach glikacji kolagenu. Polim Med. 2012; 2: 115-120.

7. Cutting K F. Wound dressings: $21^{\text {st }}$ century performance requirements. J Wound Care. 2010; 1: 4-9.

8. Robaczewska I, Filanowicz M, Cegła B. Pielęgniarskie działania oparte na stosowaniu specjalistycznych opatrunków ratujących stopę cukrzycową. Piel Pol. 2014; 1: 41-48.

9. Jemec GB, Kerihuel JC, Ousey K et al. Cost-effective use of silver dressings for the treatment of hard-to-heal chronic venous leg ulcers. PLOS One. 2014; 6: 1-6.

10. Regiel A, Kyzioł A, Arruebo M. Chitosan-silver nanocomposites - modern antibacterial materials. CHEMIK Internatiodal Edition. 2013; 8: 683-692.

11. Jawień A, Bartoszewicz M, Przondo-Mordarska A et al. Wytyczne postępowania miejscowego i ogólnego w ranach objętych procesem infekcji. Polskie Towarzystwo Leczenia Ran. Leczenie Ran. 2012; 3: 59-73.

12. Jagielski D, Jagielska A. Wykaz grup opatrunków specjalistycznych stosowanych w opiece paliatywnej. Med Paliat Prakt. 2008; 2 (2): 48-52.

13. Gloeckner Powers J, Morton LM, Phillips TJ. Dressings for chronic wounds. Dermatol Ther. 2013; 26: 197-206.

14. López PP, Soriano DP, González SA et al. Silver-containing Hydrofiber dressings to prevent progression of the radiation dermatitis in patients undergoing external beam radiotherapy and orthovoltage to the skin cancer. Rep Pract Oncol Radiother. 2013; 1: 209.

15. Sopata M, Ciupińska M, Głowacka A, Muszyński Z, Tomaszewska E. Effect of Octenisept antiseptic on bioburden of neoplastic ulcers in patients with advanced cancer. J Wound Care. 2008; 1: 24-7.

16. Bazaliński D. Trudno gojące się rany w opiece domowej. Cz. II. Zaopatrywania ran, zastosowanie opatrunków specjalistycznych i tradycyjnych w praktyce pielęgniarskiej. W: Kachaniuk H (red.). Pielęgniarska opieka nad osobami starszymi. Warszawa: Raabe; 2009. 26-41.

17. Wierzbicka M, Bień S, Osuch-Wójcikiewicz E et al. Zalecenia diagnostyczno-lecznicze w leczeniu nowotworów głowy i szyi. Pol Prz Otolaryngol. 2011; 1: 17-43.

18. Solanki G, Solanki R. Alginate dressings: an overview. Int J Biomed Res. 2012; 1: 24-28.

19. Burchacka A. Opieka paliatywna i terminalna. W: Koper A (red.). Pielęgniarstwo onkologiczne. Warszawa: PZWL; 2011. 397-417.

20. Dorai AA. Wound care with traditional, complementary and alternative medicine. Indian J Plast Surg. 2012; 2: 418-424.

21. Skórkowska-Telichowska K, Żuk M, Kulma A et al. New dressing materials derived from transgenic flax products to treat long-standing venous ulcers - a pilot study. Wound Repair Regen. 2010; 18: 168-179.

22. Skórkowska-Telichowska K, Kulma A, Szopa J. The response of diabetic foot to a new type of dressing. Int Arch Med. 2012; 5: 33. 
23. Murthy MB, Murthy BK, Bhave S. Comparison of safety and efficacy of papaya dressing with hydrogen peroxide solution on wound bed preparation in patients with wound gape. Indian J Pharmacol. 2012; 6 (44): 784-787.

24. Nayak BS, Ramdeen R, Adogwa A et al. Wound-healing potential of an ethanol extract of Carica papaya (Caricaceae) seeds. Int Wound J. 2012; 9: 650-655.

25. Zohdi RM, Bakar ZA, Zakaria N et al. Gelam (Malaleuca spp.) honey-based hydrogel as burn wound dressing. Evid Based Complement Alternat Med. 2012; 1-7.

26. Muthaiyan A, Martin EM, Natesan S et al. Antimicrobial effect and mode of action of terpeneless cold pressed valencia orange essential oil on Methicillin-Resistant Staphylococcus aureus. J App Microbiol. 2012; 5 (112): 1020-1033.

27. Grys A, Łowicki Z, Gryszczyńska A et al. Rośliny zielarskie w leczeniu chorób skóry - bezpieczeństwo i zastosowanie. Post Fitoter. 2011; 3: 191-196.

28. Nagoba BS, Wadher BJ, Rao A et al. Treatment of lepromatous ulcers using citric acid as o sole antimicrobial agent. Int Wound J. 2012; 9: 553-556.
Artykuł przyjęty do redakcji: 20.10.2015

Artykuł przyjęty do publikacji: 03.12.2015

Źródło finansowania: Praca nie jest finansowana z żadnego źródła. Konflikt interesów: Autorzy deklarują brak konfliktu interesów.

\section{Adres do korespondencji:}

Dorota Bitiucka

ul. Szpitalna 37

15-274 Białystok

tel.: 856865078

e-mail: renatasierz@wp.pl

Studenckie Koło Naukowe

przy Zakładzie Pielęgniarstwa Chirurgicznego

Uniwersytet Medyczny w Białymstoku 